\title{
Modelling and Environmental Aspects of Direct or Indirect Dimethyl Ether Synthesis Using Digestate as Feedstock
}

\author{
Aristide Giuliano*, Enrico Catizzone \\ ENEA-Italian National Agency for New Technologies, Energy and Sustainable Economic Development, Trisaia Research \\ Centre, I-75026, Rotondella, Italy
}

Corresponding Author Email: aristide.giuliano@enea.it

https://doi.org/10.18280/mmep.080514

Received: 22 January 2021

Accepted: 13 September 2021

\section{Keywords:}

digestate, gasification, dimethyl ether, process simulation, sustainability, carbon dioxide emission assessment, waste-to-chemicals

\begin{abstract}
The conversion of waste and residues towards high added value products has receiving a growing attention, as a reliable strategy to improve sustainability of emergent processes. Anaerobic digestion converts organic waste into biogas and digestate. While biogas may be used for energetic purpose, digestate has limited uses and with a low profitability. In this paper, dimethyl ether (DME) is adopted as target product which may be produced from digestate-derived syngas. Process simulation is carried out for both direct and indirect synthesis of DME and environmental aspects are assessed.
\end{abstract}

\section{INTRODUCTION}

Anaerobic digestion is well-known process that has attracted considerable attention with the rising for renewable energy and environmental protection. In particular, biogas, a mixture of methane and carbon dioxide, is currently the target product of anaerobic digestion. Biogas production and utilization give several environmental benefits such as green energy production, organic waste disposal, environmental protection, green-house-gases emission reduction [1-3]. In fact, biogas may be used for the production of electricity, heat and vehicle fuel, such as bio-methane as substitution of conventional fossil energy sources, while the anaerobic digestion address issues of disposal of agricultural residues, industrial wastes, municipal solid waste, organic waste mixtures, manure, food waste, etc. [4-6]. As an example, European Union policy estimates that at least $25 \%$ of all bioenergy can be derived from biogas, and the growing of the number of anaerobic digestion plants confirms this trend [7]. Anaerobic digestion is a complex integrated system that involve several reactions $[8,9]$. During anaerobic digestion, the organic feedstock is only partially converted to biogas. In fact, the secondary main stream of anaerobic digestion process is digestate. Digestate contains a high amount of nonbiodegradable components which is currently used as starting material for the production of nitrogen-rich organic fertilizers, avoiding the use of fossil-derived fertilizers for agricultural soil $[10,11]$. Regarding the organic municipal solid waste only, the waste generation by urban residents is expected to increase from about 3.5 Mtons/day in 2010 to more than 6 Mtons/day in 2025, with a total management cost of $\$ 375$ billion in 2025 [12]. The conversion of digestate into organic fertilizer requires time and space (stabilization plants) and the obtained product has difficulties to be accepted from community and therefore its market is limited, although it may be considered as a sustainable way to reduced GHG emission as sequestration and storage of $\mathrm{CO}_{2}$. Therefore, the research is also interested to found alternative way for the valorization of digestate. In this regard, gasification of digestate may be used to as alternative process for digestate conversion into highadded value products [13-15]. By gasification a solid carbonaceous material is converted into a fuel gas mainly composed of carbon monoxide, hydrogen, methane. The carbonaceous material reacts at temperatures of $700-900{ }^{\circ} \mathrm{C}$ with a controlled sub-stoichiometric amount of oxidant (air/oxygen or steam), leaving an inorganic residue (ash). The obtain gas stream, generally named syngas, can be used for either energetic purposes, such as in combined heat and power plants, or as reactants for the production of intermediates and fuels. For the latter case, a large amount of experimental investigations have been carried out for gasification of biomass and lignocellulose residues, while a limited number of studies are published from the gasification of digestate. Similarly, several studies have been carried out on the conversion of biomass-derived syngas into intermediates and fuels, such as methanol, dimethyl ether, Fischer-Tropsch fuels, and green hydrogen [16-20].

In particular, dimethyl ether (DME) is considered one of the most reliable candidate as circular hydrogen carrier as well as alternative fuel for diesel engine and intermediate for the production of olefin [21-23].

Dimethyl ether, with chemical formula $\mathrm{C}_{2} \mathrm{H}_{6} \mathrm{O}$, is the a colorless, non-toxic, non-corrosive and non-carcinogenic substance. The physical properties of DME are very similar to those of liquefied petroleum gas.

The lower boiling point than diesel one, leads to fast evaporation when liquid DME spray is injected into the engine cylinder improving the combustion. In addition, the low autoignition temperature permits to obtain a higher cetane number of DME than that offered from diesel fuel.

On the other hand, some disadvantages have to be accounted for a right evaluation about utilization of DME as diesel substituted. DME exhibits a Lower Heating Value (LHV) much lower than diesel $(27.6 \mathrm{MJ} / \mathrm{kg}$ vs $42.5 \mathrm{MJ} / \mathrm{kg}$ ) fuel and for this reason a larger amount of injected volume and longer injection period for DME is necessary in order to 
deliver the same amount of energy. Others disadvantages are related to necessity to change engine configuration if diesel fuel is substituted with DME fuel. Indeed, the much lower viscosity of DME causes the necessity application of special gaskets in order to avoid leakage.

DME can be produced from syngas (a mixture of carbon monoxide and hydrogen), which may be produced a variety of feed-stock including natural gas, coal, and renewables, such as biomass [24]. The most consolidated process for DME synthesis is named indirect synthesis.

In indirect synthesis, DME is produced via methanol dehydration over an acid catalyst. More details about methanol production and methanol dehydration to DME are reported elsewhere [25-33].

In the direct synthesis way methanol synthesis (typically from a $\mathrm{CO}_{2} / \mathrm{CO} / \mathrm{H}_{2}$ mixture) and dehydration process to produce dimethyl ether is carried out in a single reactor unit over a redox/acid catalyst [30].

The main steps occurring during the direct synthesis process are usually the synthesis of methanol from syngas (c) over redox catalytic function, methanol dehydration to DME over acid function (d) and eventual water gas shift reaction (WGSR) catalyzed by the redox function (d). If these three steps occur during the process the global reaction can be illustrated by equation (a); contrariwise, when WGSR does not take place, equation (b) can be used to describe thermodynamically the process. Among the above described reaction, methanol synthesis is the most equilibriumrestricted. The factors that affect theoretical equilibrium conversion are generally temperature, pressure and initial composition. The methanol synthesis reaction occurs with a decreasing of moles number and exothermically, therefore is favored at high syngas pressure and low reaction temperature. The traditional catalyst for direct synthesis of DME is a redox/acid bifunctional catalyst operating at reaction condition similar to those adopted for methanol synthesis [31].

The research is currently focused on the direct hydrogenation of carbon dioxide to dimethyl ether [32-36]. For this process, both technical and catalytic aspects are still open challenges. Actually, the one-pot conversion of carbon dioxide to DME at demonstrative scale is need to push towards a deeper assessment on the profitability of the process, even if advances in catalysis of the process are also strongly requested.

In the case of raw gasification syngas is used, both process and catalytic aspects need to be investigated in more details also at lab-scale.

This work aims to assess both the technical and environmental aspects of a process for the production of dimethyl ether from a digestate-derived syngas. In particular, on the basis of a preliminary assessment [36], in this study a comparison between indirect and direct synthesis of DME is discussed at the light of both technical and environmental considerations. This paper is written with the scope to push the research to investigate in more details about the synthesis of dimethyl ether from syngas derived from secondary streams produced in bio-refineries, such as digestate in the case of biomethane production.

\section{MATERIALS AND METHODS}

In this work, three cases were assessed in order to identify the best eco-friendly process pathway to valorise syngas obtained by digestate gasification.
Process design tools [37] were used calculate all material and energy balances of the process schemes.

Indirect synthesis of DME was proposed in Figure 1a. In this scheme there are two different recycles:

1. unreacted syngas is recycled to the methanol synthesis reactor;

2. unreacted methanol is recycled to DME synthesis reactor.
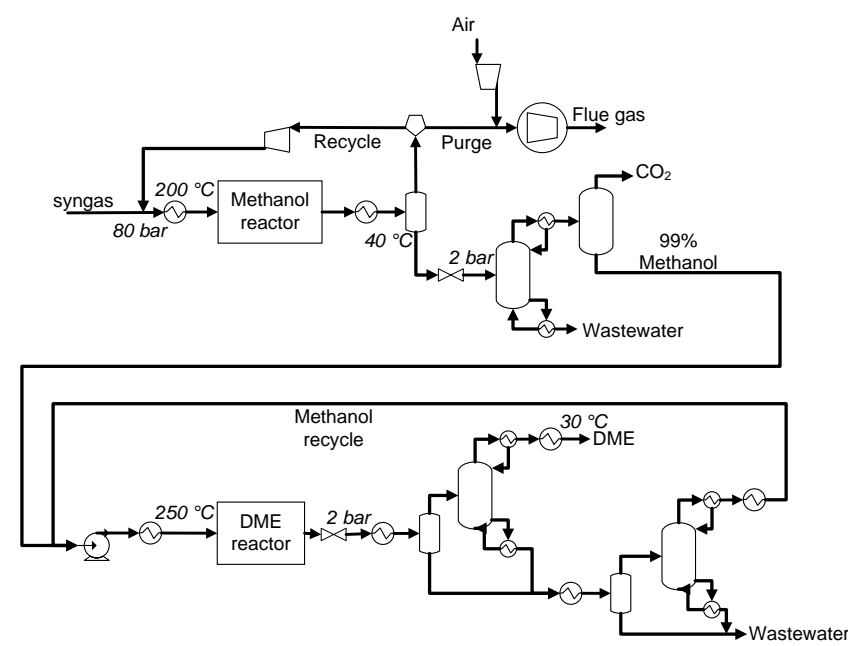

(a)

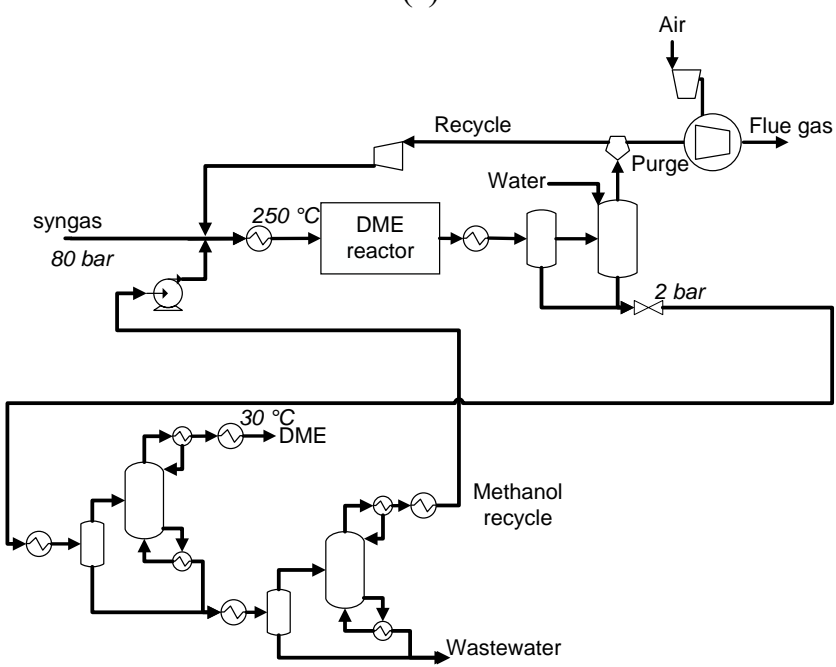

(b)
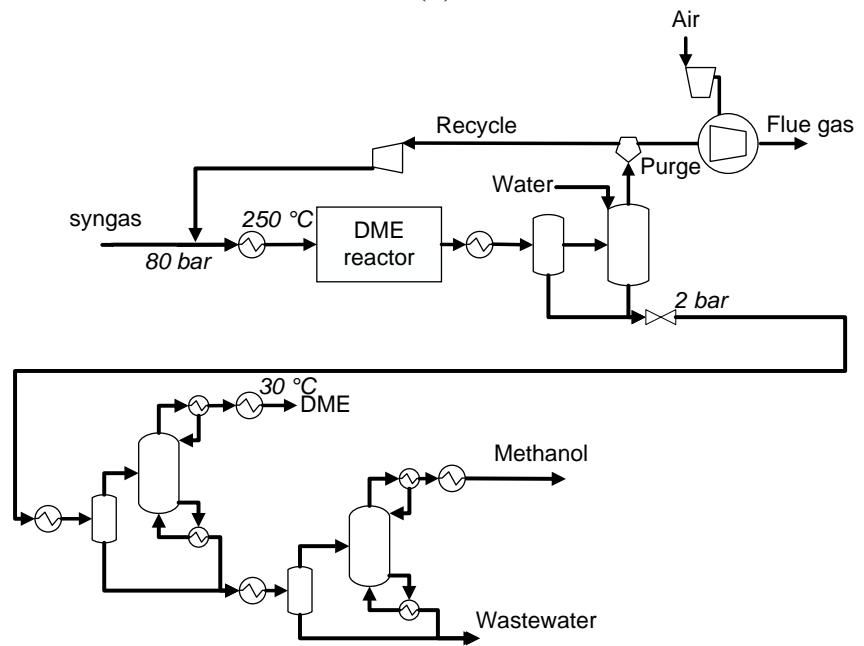

(c)

Figure 1. Process flowsheet for the indirect DME-synthesis case (a); direct DME synthesis with recycle of methanol (b); direct DME synthesis without recycle of methanol (c) 
Syngas and methanol recycled streams are necessary because of low one-step conversions in the methanol synthesis step [20], typical of DME indirect synthesis step [33].

Figure $1 \mathrm{~b}$ shows the process flowsheet of the direct DME synthesis case recycling the produced methanol as by-product in the synthesis reactor. A particularity of this scheme consists in the washing column after synthesis reactor to absorb DME in the water solution in order to recycle unconverted syngas [38].

The last flowsheet consists in direct DME synthesis without the methanol recycle. Figure 1c shows the methanol produced in the main reactor purified in the second distillation column and, consequently, selling as pure methanol.

Using a commercial software, the Redlich-Kwong-Soave thermodynamic equation of state was adopted to simulate high-pressure systems, NRTL-RK was used for distillation columns and flash separation units [39].

Table 1 shows the molar composition of the adopted syngas. It was from a previous work [40], produced by the digestate gasification. After syngas cleaning [41], WGS step [42], carbon capture and storage process [43], a conditioned syngas ready to be sent to synthesis reactors can be obtained.

Table 1. Syngas compositions (\%vol $\left.\mathrm{l}_{\text {dry }}\right)[42,37]$

\begin{tabular}{cc}
\hline From Carbon Capture and Storage (CCS) \\
\hline $\mathrm{H}_{2}$ & 21.7 \\
$\mathrm{CO}$ & 7.1 \\
$\mathrm{CO}_{2}$ & 2.3 \\
$\mathrm{CH}_{4}$ & 5.0 \\
$\mathrm{C}_{2} \mathrm{H}_{6}$ & 1.5 \\
$\mathrm{~N}_{2}$ & 62.5 \\
\hline
\end{tabular}

In the previous work [37] three process sections were simulated and assessed:

1. digestate gasification;

2. water gas shift;

3. carbon dioxide capture and storage.

Resulting syngas is shown in Table 1 . More than $60 \% \mathrm{vol}_{\mathrm{DRY}}$ consists in residue nitrogen of the gasification air. Content in $\mathrm{CO}+\mathrm{CO}_{2}$ is lower than previous step syngas because of carbon capture process. In particular, about $69 \%$ of carbon is captured and stored. However, $\mathrm{H} / \mathrm{C}$ molar ratio increases from 0.45 to 2.3 , optimal value for methanol/DME synthesis [43]. The final value for the ratio $\left(\mathrm{H}_{2}-\mathrm{CO}_{2}\right) /\left(\mathrm{CO}+\mathrm{CO}_{2}\right)$ is equal to 2.1 [20]. Each synthesis reactor was simulated by an equilibrium reactor in order to consider the best possible performances.

\subsection{Indirect DME synthesis}

Methanol synthesis reactions of Table 2 were adopted to simulate methanol synthesis via both $\mathrm{CO}$ and $\mathrm{CO}_{2}$ hydrogenation [42].

Table 2. Reactions set of synthesis of methanol

\begin{tabular}{lcc}
\hline & Reaction & $\begin{array}{c}\text { Reaction Heat } \\
{[\mathbf{k J} / \mathbf{m o l}]}\end{array}$ \\
\hline (a) & $\mathrm{CO}_{2}+3 \mathrm{H}_{2}=\mathrm{CH}_{3} \mathrm{OH}+\mathrm{H}_{2} \mathrm{O}$ & -49 \\
(b) & $\mathrm{CO}+2 \mathrm{H}_{2}=\mathrm{CH}_{3} \mathrm{OH}$ & -91 \\
(c) & $\mathrm{CO}+\mathrm{H}_{2} \mathrm{O}=\mathrm{CO}_{2}+\mathrm{H}_{2}$ & -41 \\
\hline
\end{tabular}

The exothermicity of the methanol synthesis favours the syngas conversion at low temperature. The fresh syngas stream was mixed with recycle stream (unreacted syngas) before synthesis reactor, heated up to $200^{\circ} \mathrm{C}$ and fed to the methanol synthesis adiabatic reactor. Pressure drop was assumed equal to 2 bar for the methanol synthesis reactor. Concerning operating pressure, an 80 bar pressure is considered to favour thermodynamics. Similar values are also adopted at industrial scale [41].

The light gases were separated in a flash-phase-separator at $40^{\circ} \mathrm{C}$. For the recycle, most gases were re-compressed at 80 bar and sent to the reactor. The purge gas was used as fuel for the electricity production. The liquid stream (methanol + water) was expanded to have cheaper purification equipment, in a throttling valve at 2 bar. A tray distillation column was used to separate the wastewater from methanol. Pure methanol (liquid) was pumped until to $30 \mathrm{bar}$ and then heated to $250^{\circ} \mathrm{C}$ for the DME synthesis, which is carried out in a secondary synthesis reactor (pressure drop of 2 bar).

DME synthesis reaction is a dehydration of methanol:

$$
2 \mathrm{CH}_{3} \mathrm{OH}=\mathrm{CH}_{3} \mathrm{OCH}_{3}+\mathrm{H}_{2} \mathrm{O}
$$

with a reaction heat of $-24 \mathrm{~kJ} / \mathrm{mol}$ (exothermic reversible) [43]. This reaction proceeds without mole number variation. For this reason, operation pressure does not affect equilibrium conversion, while low reaction temperatures have a thermodynamic benefit toward DME production. For this reason, the process pressure was lower than methanol synthesis pressure.

The DME-rich stream was the expanded to recovery DME in the vapour phase. Due to traces of methanol, this stream was sent to a distillation column to obtain pure DME.

Column bottom stream was sent to another distillation column to recycle unconverted methanol [44].

\subsection{Direct DME synthesis}

In the direct DME synthesis flowsheets, a set of reaction (a), (b), (c), (d), was considered to simulate the main reaction process. Because of the methanol dehydration (d) is a reaction slower than methanol synthesis, an adiabatic reactor starting from $250^{\circ} \mathrm{C}$ was used to convert directly the syngas to DME. After products cooling, the gaseous stream was sent to an absorption column to make liquid DME and to separe volatile volatile compounds [44]. The gas stream was sent to a split to divide purge gas and recycling gas. Solvent (water) and liquid compounds were expanded to 2 bar for the DME purification by distillation. An evaporator was used to obtain the DMErich stream and a liquid stream. In DME-rich stream there are trace of methanol, because of this a first distillation column was necessary. From the top of the column pure DME was obtained. The bottom stream and the liquid stream (rich in methanol and water) were heated and sent to a second distillation column to recovery methanol for the recycle of it. From the bottom a wastewater stream was obtained without DME and, so, able to absorb again DME in the absorber. For the case without methanol recycle, from the second distillation column methanol has a purity sufficient to be sold.

\subsection{Environmental impact analysis}

The total $\mathrm{CO}_{2}$-equivalent emission was adopted in order to assess the environmental impact analysis. Table 3 reports the equivalent emission factors for each main process stream of the flowsheets. In particular, a negative $\mathrm{CO}_{2}$-equivalent emission value was associated with digestate. This because the 
examined process avoids the digestate disposal in a landfill, so its environmental impact. The electricity production saving was considered equal to that of the fossil-based energy production system.

The main direct $\mathrm{CO}_{2}$ emission point is the-flue gases of the combustion of purge gas.

Table 3. $\mathrm{CO}_{2}$ equivalent emission parameters

\begin{tabular}{cc}
\hline Process item & $\begin{array}{c}\mathrm{CO}_{2} \text { equivalent } \\
\text { emissions }\end{array}$ \\
\hline Green electricity $\left(\mathrm{kg}_{\mathrm{CO} 2 \mathrm{eq}} / \mathrm{MWhe}\right)$ & -600 \\
{$[45]$} & $-1^{\prime} 643$ \\
MeOH $\left(\mathrm{kg}_{\mathrm{CO} 2 \mathrm{eq}} / \mathrm{t}\right)[37]$ & 6.5 \\
Process water $\left(\mathrm{kg}_{\mathrm{CO} 2 \mathrm{eq}} / \mathrm{t}\right)[46]$ & 500 \\
Wastewater $\left(\mathrm{kg}_{\mathrm{CO} 2 \mathrm{eq}} / \mathrm{t}\right)[46]$ & 1,821 \\
Biochar residual $\left(\mathrm{kg}_{\mathrm{CO} 2 \mathrm{eq}} / \mathrm{t}\right)[47]$ & \\
\hline
\end{tabular}

\section{RESULTS AND DISCUSSION}

A plant size equal to $100^{\prime} 000 \mathrm{t} / \mathrm{y}$ of digestate was considered as collective digestate treatment plant [47].

For indirect synthesis, the global conversion and a one-step conversion of $\mathrm{CO}+\mathrm{CO}_{2}$ to $\mathrm{MeOH}$ of $82 \%$ and $17 \%$ respectively, were found. Thanks to the syngas recycle the global conversion is higher. A purge ratio equal to $12 \%$ was fixed to avoid decreasing $\mathrm{H} / \mathrm{C}$ ratio in the inlet stream to the reactor. The global methanol conversion in the main reactor was equal to $94 \%$ (thanks to recycle) with a ratio $\mathrm{MeOH}_{\text {recycled }} / \mathrm{MeOH}_{\text {fresh }}$ of $\mathbf{1 3 \%}$.

For the direct synthesis, the conversion of CO was 59\%, while $\mathrm{CO}_{2}$ was produced in the reactor because of WGS reaction (c). the molar yield of $\mathrm{CO}+\mathrm{CO}_{2}$ to $\mathrm{MeOH}$ was equal to $0.3 \%$ and $1.8 \%$ for case with and without methanol recycle respectively. This due to the higher partial pressure of methanol in the reactor in the case with recycle.

For the indirect synthesis case this yield was calculated respect to the initial syngas.

To consider the number of carbon atoms in DME, the molar yield was:

$$
y_{D M E}=\frac{2 D M E}{C O+C O_{2}}
$$

Figure 2 shows the molar yield from $\mathrm{CO}+\mathrm{CO}_{2}$ to DME. The lowest yield (37.9\%) was obtained for the indirect synthesis, since there isn't the effect of simultaneous conversion of methanol in the same reactor. The highest yield $(45.6 \%)$ was found for the direct synthesis with methanol recycle, thanks to double carbon recycle of syngas and methanol.

Figure 3 shows the green electricity production for three cases. Without methanol recycle, the purge gas combustion (fixed to $12 \%$ ) produces less electricity $(1.8 \mathrm{MWe})$ than other cases. In this case, in fact, the recycled material is lower due to:

1. higher $\mathrm{CO}+\mathrm{CO}_{2}$ conversion, as previously highlighted, and so lower LHV of the recycle stream;

2. energy content of the sold methanol is lost.

Consequently, in this case $10 \%$ less energy than indirect synthesis case was produced. When DME global yield is lower, for the indirect synthesis, higher values of carbon compounds are available in the gas stream after methanol reactor and, consequently, in the purge gas. For this case, 2.0 MWe of green electricity are produced. The middle yield to power is obtained for the direct synthesis with methanol recycle. This is due to the combination between:

1. higher yield to products of $\mathrm{CO}$, decreasing $\mathrm{LHV}$ of purge gas;

2. lower loss of energy by material outlet streams, increasing the flowrate of the recycle gas.

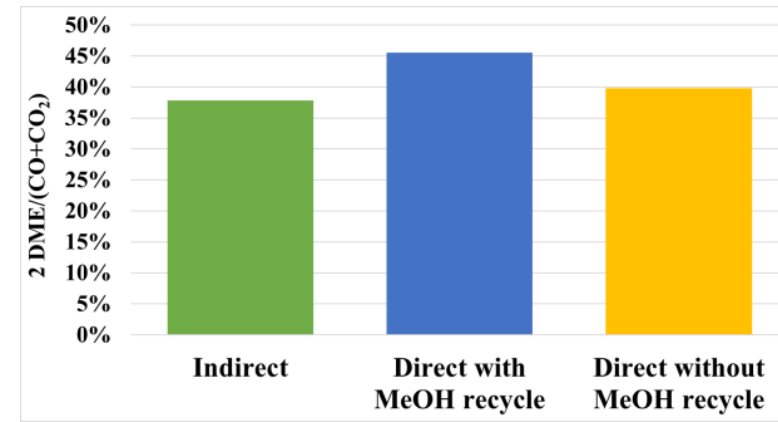

Figure 2. Molar yield of syngas after carbon capture to DME

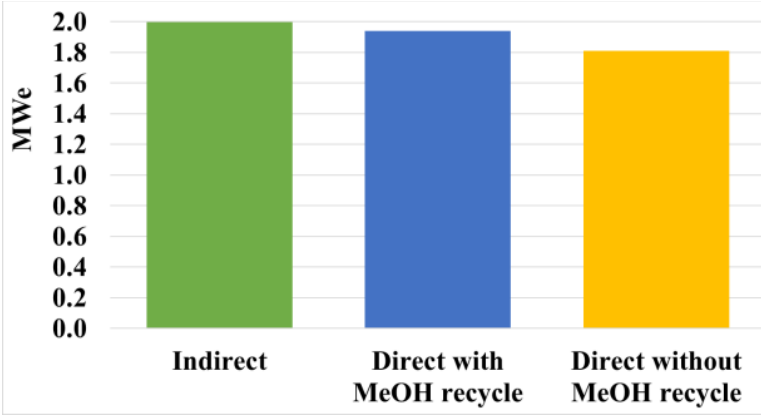

Figure 3. Green electricity production

Table 4 shows the process flowrates of three considered flowsheets. Wastewater for direct synthesis has a similar value, but $350 \%$ higher than indirect synthesis case. For the indirect synthesis, in fact, are not necessary process water for the DME absorption from the gaseous stream, to recover unreacted syngas. For the same reason, also the process water is higher for the direct synthesis cases.

Table 4. Process simulation main results

\begin{tabular}{cccc}
\hline Process parameter & Indirect & $\begin{array}{c}\text { Direct } \\
\text { with } \\
\text { MeOH } \\
\text { recycle }\end{array}$ & $\begin{array}{c}\text { Direct } \\
\text { without } \\
\text { MeOH } \\
\text { recycle }\end{array}$ \\
\hline Wastewater $(\mathrm{kt} / \mathrm{y})$ & 1.5 & 5.3 & 5.2 \\
Process water $(\mathrm{kt} / \mathrm{y})$ & 12.4 & 16.2 & 16.1 \\
DME production $(\mathrm{kt} / \mathrm{y})$ & 3.2 & 3.9 & 3.4 \\
$\mathrm{MeOH}$ recycled/produced $(\mathrm{kt} / \mathrm{y})$ & 5.3 & 0.9 & 0.9 \\
\hline
\end{tabular}

In terms of DME production, from $100 \mathrm{kt} / \mathrm{y}$ of digestate are obtained about 3-4 kt/y of pure DME. In particular, the production of DME is the same of DME yield of Figure 2. The DME recovery is about $99 \%$. Produced methanol can be used to:

1. produce DME in the second reaction step (indirect synthesis);

2. be recycled to the DME reactor (direct synthesis with $\mathrm{MeOH}$ recycle);

3. be sold for the third case.

In the first case, methanol production in the reactor is the highest $(5.3 \mathrm{kt} / \mathrm{y})$ and it is the main reactant to produce the final 
DME. For both direct synthesis cases $900 \mathrm{t} / \mathrm{y}$ of methanol are recycled or sold.

The results in terms of $\mathrm{CO}_{2}$ equivalent emissions are shown in Table 5. The solid residue from the digestate gasification was considered disposed in a landfill. The direct $\mathrm{CO}_{2}$ emissions from purge gas combustion represent the second larger environmental impact cause: between 22.5 and 22.9 $\mathrm{kt}_{\mathrm{CO} 2} / \mathrm{y}$. The largest amount of "C" (35.5 kt $\left.\mathrm{kO}_{\mathrm{CO}} / \mathrm{y}\right)$ atoms of gasification syngas was captured Selexol ${ }^{\circledR}$, after increasing of $\mathrm{CO}_{2}$ partial pressure by WGS section. The $\mathrm{CO}_{2 \mathrm{eq}}$ saving correspondent to the green electricity production is about 7.8$8.6 \mathrm{kt}_{\mathrm{CO} 2 \mathrm{eq}} / \mathrm{y}$, less than $10 \%$ of the total emissions.

Table 5. Annual $\mathrm{CO}_{2}$ equivalent emissions $\left(\mathrm{kt}_{\mathrm{CO} 2 \mathrm{eq}} / \mathrm{y}\right)$. Negative values are $\mathrm{CO}_{2}$ savings

\begin{tabular}{cccc}
\hline $\begin{array}{c}\text { Process } \\
\text { item }\end{array}$ & Indirect & $\begin{array}{c}\text { Direct with } \\
\text { MeOH recycle }\end{array}$ & $\begin{array}{c}\text { Direct without } \\
\text { MeOH recycle }\end{array}$ \\
\hline $\begin{array}{c}\text { Char to } \\
\text { disposal }\end{array}$ & 71 & 71 & 71 \\
Wastewater & 0.8 & 2.6 & 2.6 \\
$\begin{array}{c}\text { Process } \\
\text { water }\end{array}$ & 0.08 & 0.10 & 0.10 \\
$\mathrm{CO}_{2}$ in flue \\
gas & 22.9 & 22.7 & 22.5 \\
MeOH & - & - & -1.4 \\
$\begin{array}{c}\text { Green } \\
\text { electricity }\end{array}$ & -8.6 & -8.4 & -7.8 \\
\hline Total & 86.1 & 88.0 & 86.9 \\
\hline
\end{tabular}

The differences between the impact of three cases related to wastewater and process water are due essentially to greater amount of water necessary in the direct synthesis to absorb DME from the reactor outlet stream. The behavior of $\mathrm{CO}_{2}$ direct emissions and of the green electricity production emissions/savings is the same of Figure 3. Decreasing LHV of purge gas, $\mathrm{CO}_{2}$ in flue gas, power production and savings from green electricity decrease. The specific deviation between the largest saving and the lowest is the same of the power production, equal to about $10 \%$. While between the largest and the lowest direct emission is equal to $1.7 \%$. This low value is due to the large amount of $\mathrm{CH}_{4}(5.7 \%)$ in the purge gas, because this is an inert compound. A low value of saving from bio-methanol production was found for the direct synthesis without methanol recycle case. Only $1.4 \%$ of the emissions, in fact, was saved thanks to bio-methanol.

Globally, the total equivalent $\mathrm{CO}_{2}$ emissions have the same trend of the DME yield. In particular, $1.9 \mathrm{kt}_{\mathrm{CO} 2 \mathrm{eq}} / \mathrm{y}$ more are emitted for the direct synthesis with recycle case respect to the indirect synthesis case. This due essentially to higher emissions of the wastewater treatment, from the different DME purification process must be used if the synthesis is direct.

Finally, Figure 4 shows the specific environmental impact associated to DME produced from digestate gasification. The highest impact was found for the indirect synthesis case (27 $\left.\mathrm{kg}_{\mathrm{CO} 2 \mathrm{eq}} / \mathrm{kg}_{\mathrm{DME}}\right)$. The main reason is the low yield to DME of the synthesis by double step process.

The direct synthesis without methanol recycle has an impact of $26 \mathrm{~kg}_{\mathrm{CO} 2 \mathrm{eq}} / \mathrm{kg}_{\mathrm{DME}}$, closer to indirect than direct with recycle. This because of a medium DME yield, but with higher emissions from wastewater treatment and lower savings from the green power production. The bio-methanol production, in fact, is not able to make environmentally convenient the third case, due to low additional saving. The best solution was found for the direct synthesis with methanol recycle. In this case, yield to DME is the highest, the power production and lower direct emissions are sufficient to partially compensate higher emissions associated to wastewater.

Future developments of this work should investigate the process optimization of the WGS and CCS sections in order to obtain a syngas, and consequently a conversion by direct synthesis with methanol recycle, as the optimal one. The limit of this work, in fact, consists in the low DME yields obtained considering the digestate gasification downstream as syngas (11.9 - 14.3\% mol). Optimizing the section of WGS and CCS would allow to allocate less carbon $\left(\mathrm{CO}+\mathrm{CO}_{2}\right)$ to the $\mathrm{CO}_{2}$ capture processes and more carbon available for conversion to DME.

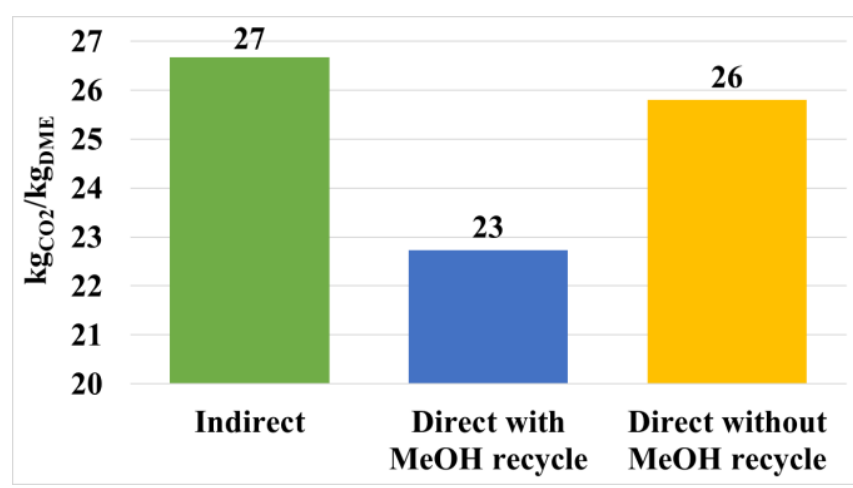

Figure 4. Environmental impact per kg of DME for each considered case

\section{CONCLUSIONS}

In this work three process flowsheet were assessed for the production of DME using a syngas obtained from the digestate gasification. In particular, indirect synthesis, direct synthesis with methanol recycle and direct synthesis without methanol recycle were simulated and evaluated for the environmental analysis. The specific $\mathrm{CO}_{2}$ equivalent emissions $\left(\mathrm{kg}_{\mathrm{CO} 2 \mathrm{eq}} / \mathrm{kg}_{\mathrm{DME}}\right)$ were calculated and used as the main parameter to consider a process flowsheet preferable from an environmental point of view. Following that, the main parameter result to make one process case better than another consists in DME yield. In particular, the lowest emissions are obtained for the direct synthesis case with recycling of methanol. Despite this, thanks to the higher global yield to DME (45\%), this process flowsheet is the optimal one, with an environmental impact of $23 \mathrm{~kg}_{\mathrm{CO} 2 \mathrm{eq}} / \mathrm{kg}_{\mathrm{DME}}$. Using this process, about $1.9 \mathrm{ktCO}_{2} / \mathrm{y}$ of emissions can be avoided respect to the indirect synthesis process pathway. The indirect synthesis process flowsheet presents a higher green electricity production due to high waste-stream flowrate to burn. On the other hand, this flowsheet does not valorize the carbon content of digestate to DME (yield equal to $38 \%$ ). In conclusion, the digestate valorization can be an optimal alternative to the utilization as a soil conditioner producing chemicals (DME), energy (green power) using the gasification process and CCS methods. More attention has to be paid to the WGS and CCS sections. Future developments will concern the process optimization of the WGS and CCS sections in order to increase the global yields to DME by reducing the amount of $\mathrm{CO}_{2}$ captured. 


\section{REFERENCES}

[1] Kougias, P.G., Angelidaki, I. (2018). Biogas and its opportunities-A review. Frontiers of Environmental Science \& Engineering, 12(3): 14. https://doi.org/10.1007/s11783-018-1037-8

[2] Mao, C., Feng, Y., Wang, X., Ren, G. (2015). Review on research achievements of biogas from anaerobic digestion. Renewable and Sustainable Energy Reviews, 45: 540-555. https://doi.org/10.1016/j.rser.2015.02.032

[3] Hijazi, O., Munro, S., Zerhusen, B., Effenberger, M. (2016). Review of life cycle assessment for biogas production in Europe. Renewable and Sustainable Energy Reviews, 54: 1291-1300. https://doi.org/10.1016/j.rser.2015.10.013

[4] Carrere, H., Antonopoulou, G., Affes, R., Passos, F., Battimelli, A., Lyberatos, G., Ferrer, I. (2016). Review of feedstock pretreatment strategies for improved anaerobic digestion: From lab-scale research to full-scale application. Bioresource Technology, 199: 386-397. https://doi.org/10.1016/j.biortech.2015.09.007

[5] Shi, L., Simplicio, W.S., Wu, G., Hu, Z., Hu, H., Zhan, $X$. (2018). Nutrient recovery from digestate of anaerobic digestion of livestock manure: A review. Current Pollution Reports, 4(2): 74-83. https://doi.org/10.1007/s40726-018-0082-z

[6] Ren, Y., Yu, M., Wu, C., Wang, Q., Gao, M., Huang, Q., Liu, Y. (2018). A comprehensive review on food waste anaerobic digestion: Research updates and tendencies. Bioresource Technology, 247: 1069-1076. https://doi.org/10.1016/j.biortech.2017.09.109

[7] Edwards, J., Othman, M., Burn, S. (2015). A review of policy drivers and barriers for the use of anaerobic digestion in Europe, the United States and Australia. Renewable and Sustainable Energy Reviews, 52: 815828. https://doi.org/10.1016/j.rser.2015.07.112

[8] Khan, I.U., Othman, M.H.D., Hashim, H., Matsuura, T., Ismail, A.F., Rezaei-DashtArzhandi, M., Azelee, I.W. (2017). Biogas as a renewable energy fuel-A review of biogas upgrading, utilisation and storage. Energy Conversion and Management, 150: 277-294. https://doi.org/10.1016/j.enconman.2017.08.035

[9] Wu, D., Li, L., Zhao, X., Peng, Y., Yang, P., Peng, X. (2019). Anaerobic digestion: A review on process monitoring. Renewable and Sustainable Energy Reviews, 103: 1-12. https://doi.org/10.1016/j.rser.2018.12.039

[10] Peng, W., Lü, F., Hao, L., Zhang, H., Shao, L., He, P. (2020). Digestate management for high-solid anaerobic digestion of organic wastes: A review. Bioresource Technology, 297: 122485 https://doi.org/10.1016/j.biortech.2019.122485

[11] Nkoa, R. (2014). Agricultural benefits and environmental risks of soil fertilization with anaerobic digestates: A review. Agronomy for Sustainable Development, 34(2): 473-492. https://doi.org/10.1007/s13593-013-0196-z

[12] Hoornweg, D., Bhada-Tata, P. (2012). What a waste: A global review of solid waste management. https://openknowledge.worldbank.org/handle/10986/17 388

[13] Antoniou, N., Monlau, F., Sambusiti, C., Ficara, E., Barakat, A., Zabaniotou, A. (2019). Contribution to circular economy options of mixed agricultural wastes management: Coupling anaerobic digestion with gasification for enhanced energy and material recovery. Journal of Cleaner Production, 209: 505-514. https://doi.org/10.1016/j.jclepro.2018.10.055

[14] Freda, C., Cornacchia, G., Romanelli, A., Valerio, V., Grieco, M. (2018). Sewage sludge gasification in a bench scale rotary kiln. Fuel, 212: 88-94. https://doi.org/10.1016/j.fuel.2017.10.013

[15] Chen, G., Guo, X., Cheng, Z., Yan, B., Dan, Z., Ma, W. (2017). Air gasification of biogas-derived digestate in a downdraft fixed bed gasifier. Waste Management, 69: 162-169. https://doi.org/10.1016/j.wasman.2017.08.001

[16] dos Santos, R.G., Alencar, A.C. (2020). Biomass-derived syngas production via gasification process and its catalytic conversion into fuels by Fischer Tropsch synthesis: A review. International Journal of Hydrogen Energy, 45(36): 18114-18132. https://doi.org/10.1016/j.ijhydene.2019.07.133

[17] Patel, M., Zhang, X., Kumar, A. (2016). Technoeconomic and life cycle assessment on lignocellulosic biomass thermochemical conversion technologies: A review. Renewable and Sustainable Energy Reviews, 53: 1486-1499. https://doi.org/10.1016/j.rser.2015.09.070

[18] Parthasarathy, P., Narayanan, K.S. (2014). Hydrogen production from steam gasification of biomass: Influence of process parameters on hydrogen yield-a review. Renewable Energy, 66: 570-579. https://doi.org/10.1016/j.renene.2013.12.025

[19] Asadullah, M. (2014). Biomass gasification gas cleaning for downstream applications: A comparative critical review. Renewable and Sustainable Energy Reviews, 40: 118-132. https://doi.org/10.1016/j.rser.2014.07.132

[20] Giuliano, A., Catizzone, E., Barisano, D., Nanna, F., Villone, A., De Bari, I. (2019). Towards methanol economy: A techno-environmental assessment for a biomethanol OFMSW/biomass/carbon capture-based integrated plant. Int. J. Heat Technol, 37: 665-674.

[21] Catizzone, E., Freda, C., Braccio, G., Frusteri, F., Bonura, G. (2021). Dimethyl ether as circular hydrogen carrier: Catalytic aspects of hydrogenation/dehydrogenation steps. Journal of Energy Chemistry, 58: 55-77. https://doi.org/10.1016/j.jechem.2020.09.040

[22] Pérez-Uriarte, P., Ateka, A., Gayubo, A.G., CorderoLanzac, T., Aguayo, A.T., Bilbao, J. (2017). Deactivation kinetics for the conversion of dimethyl ether to olefins over a HZSM-5 zeolite catalyst. Chemical Engineering Journal, 311: 367-377. https://doi.org/10.1016/j.cej.2016.11.104

[23] Catizzone, E., Cirelli, Z., Aloise, A., Lanzafame, P., Migliori, M., Giordano, G. (2018). Methanol conversion over ZSM-12, ZSM-22 and EU-1 zeolites: From DME to hydrocarbons production. Catalysis Today, 304: 39-50. https://doi.org/10.1016/j.cattod.2017.08.037

[24] Mevawala, C., Jiang, Y., Bhattacharyya, D. (2019). Techno-economic optimization of shale gas to dimethyl ether production processes via direct and indirect synthesis routes. Applied Energy, 238: 119-134. https://doi.org/10.1016/j.apenergy.2019.01.044

[25] Molino, A., Larocca, V., Chianese, S., Musmarra, D. (2018). Biofuels production by biomass gasification: A review. $\quad$ Energies, 811. https://doi.org/10.3390/en11040811

[26] Bateni, H., Able, C. (2019). Development of 
heterogeneous catalysts for dehydration of methanol to dimethyl ether: A review. Catalysis in Industry, 11(1): 733. https://doi.org/10.1134/S2070050419010045

[27] Catizzone, E., Migliori, M., Aloise, A., Lamberti, R., Giordano, G. (2019). Hierarchical low $\mathrm{Si} / \mathrm{Al}$ ratio ferrierite zeolite by sequential postsynthesis treatment: catalytic assessment in dehydration reaction of methanol. Journal of Chemistry, pp. 1-9. https://doi.org/10.1155/2019/3084356

[28] Catizzone, E., Migliori, M., Mineva, T., van Daele, S., Valtchev, V., Giordano, G. (2020). New synthesis routes and catalytic applications of ferrierite crystals. Part 1: 1, 8-Diaminooctane as a new OSDA. Microporous and Mesoporous $\quad$ Materials, 109987. https://doi.org/10.1016/j.micromeso.2019.109987

[29] Palčić, A., Catizzone, E. (2021). Application of nanosized zeolites in methanol conversion processes: A short review. Current Opinion in Green and Sustainable Chemistry, 27: 100393. https://doi.org/10.1016/j.cogsc.2020.100393

[30] Gogate, M.R. (2018). The direct, one-step process for synthesis of dimethyl ether from syngas. III. DME as a chemical feedstock. Petroleum Science and Technology, 36(8): https://doi.org/10.1080/10916466.2018.1428630

[31] Ali, K.A., Abdullah, A.Z., Mohamed, A.R. (2015). Recent development in catalytic technologies for methanol synthesis from renewable sources: A critical review. Renewable and Sustainable Energy Reviews, 44: 508-518. https://doi.org/10.1016/j.rser.2015.01.010

[32] Catizzone, E., Bonura, G., Migliori, M., Braccio, G., Frusteri, F., Giordano, G. (2019). Direct $\mathrm{CO}_{2}$-todimethyl Ether Hydrogenation over CuZnZr/zeolite Hybrid Catalyst: New evidences on the interaction between acid and metal sites. Ann. Chim. - Sci. des Matériaux, 43: 141-149. https://doi.org/10.18280/acsm.430302

[33] Bonura, G., Cannilla, C., Frusteri, L., Catizzone, E., Todaro, S., Migliori, M. (2020). Interaction effects between $\mathrm{CuO}-\mathrm{ZnO}-\mathrm{ZrO}_{2}$ methanol phase and zeolite surface affecting stability of hybrid systems during onestep $\mathrm{CO}_{2}$ hydrogenation to DME. Catalysis Today, 345: 175-182. https://doi.org/10.1016/j.cattod.2019.08.014

[34] Catizzone, E., Bonura, G., Migliori, M., Frusteri, F., Giordano, G. (2018). $\mathrm{CO}_{2}$ recycling to dimethyl ether: State-of-the-art and perspectives. Molecules, 23(1): 31. https://doi.org/10.3390/molecules23010031

[35] Centi, G., Quadrelli, E.A., Perathoner, S. (2013). Catalysis for CO 2 conversion: A key technology for rapid introduction of renewable energy in the value chain of chemical industries. Energy \& Environmental Science, $6(6)$ : 1711-1731. https://doi.org/10.1039/c3ee00056g

[36] Giuliano, A., Catizzone, E. (2020). Process simulation and environmental assessment of the production of dimethyl ether from digestate. Tecnica Italiana-Italian Journal of Engineering Science, 64(2-4): 173-178. https://doi.org/10.18280/ti-ijes.642-407

[37] Galanopoulos, C., Giuliano, A., Barletta, D., Zondervan, E. (2020). An integrated methodology for the economic and environmental assessment of a biorefinery supply chain. Chemical Engineering Research and Design, 160: 199-215. https://doi.org/10.1016/j.cherd.2020.05.016

[38] Han, Y., Zhang, H., Ying, W., Fang, D. (2009). Modeling and simulation of production process on dimethyl ether synthesized from coal-based syngas by one-step method. Chinese Journal of Chemical Engineering, 17(1): 108112. https://doi.org/10.1016/S1004-9541(09)60041-0

[39] Giuliano, A., Freda, C., Catizzone, E. (2020). Technoeconomic assessment of bio-syngas production for methanol synthesis: A focus on the water-gas shift and carbon capture sections. Bioengineering, 7(3): 70. https://doi.org/10.3390/bioengineering7030070

[40] Freda, C., Nanna, F., Villone, A., Barisano, D., Brandani, S., Cornacchia, G. (2019). Air gasification of digestate and its co-gasification with residual biomass in a pilot scale rotary kiln. International Journal of Energy and Environmental Engineering, 10(3): 335-346. https://doi.org/10.1007/s40095-019-0310-3

[41] Giuliano, A., Poletto, M., Barletta, D. (2018). Pure hydrogen co-production by membrane technology in an IGCC power plant with carbon capture. International Journal of Hydrogen Energy, 43(41): 19279-19292. https://doi.org/10.1016/j.ijhydene.2018.08.112

[42] Chi, J., Li, K., Zhang, S., Zhu, X., Zhao, L., Wang, B., Xiao, Y. (2020). Process simulation and integration of IGCC systems with novel mixed ionic and electronic conducting membrane-based water gas shift membrane reactors for $\mathrm{CO}_{2}$ capture. International Journal of Hydrogen Energy, 45(27): 13884-13898. https://doi.org/10.1016/j.ijhydene.2020.03.138

[43] Padurean, A., Cormos, C.C., Agachi, P.S. (2012). Precombustion carbon dioxide capture by gas-liquid absorption for Integrated Gasification Combined Cycle power plants. International Journal of Greenhouse Gas Control, 7:

$1-11$. https://doi.org/10.1016/j.ijggc.2011.12.007

[44] Azizi, Z., Rezaeimanesh, M., Tohidian, T., Rahimpour, M.R. (2014). Dimethyl ether: A review of technologies and production challenges. Chemical Engineering and Processing: Process Intensification, 82: 150-172. https://doi.org/10.1016/j.cep.2014.06.007

[45] Giuliano, A., Bari, I.D., Motola, V., Pierro, N., Giocoli, A., Barletta, D. (2019). Techno-environmental assessment of two biorefinery systems to valorize the residual lignocellulosic biomass of the Basilicata region. https://doi.org/10.18280/mmep.060301

[46] da Silva, A.R.G., Giuliano, A., Errico, M., Rong, B.G., Barletta, D. (2019). Economic value and environmental impact analysis of lignocellulosic ethanol production: Assessment of different pretreatment processes. Clean Technologies and Environmental Policy, 21(3): 637-654. https://doi.org/10.1007/s10098-018-01663-z

[47] Giuliano, A., Catizzone, E., Freda, C., Cornacchia, G. (2020). Valorization of OFMSW digestate-derived syngas toward methanol, hydrogen, or electricity: Process simulation and carbon footprint calculation. Processes, 8(5): 526. https://doi.org/10.3390/pr8050526

\section{NOMENCLATURE AND ABBREVIATIONS}

DME Dimethyl Ether

WGSR Water Gas Shift Reaction

$\mathrm{MeOH}$ Methanol

LHV Lower Heating Value

CCS Carbon Capture and Storage 